Gut, 1984, 25, 942-947

\title{
Nutritional support of malnourished lactose intolerant African patients
}

\author{
S J D O'KEEFE, J K ADAM, E CAKATA, AND S EPSTEIN \\ From the Gastrointestinal Unit, Department of Medicine, University of Natal/King Edward VIII Hospital, \\ Durban, South Africa
}

SUMMARY The effectiveness of two commonly available liquid diets was assessed in 40 severely malnourished black African patients. All patients were shown to have normal xylose absorption. The diets were given according to the manufacturer's recommendations. One diet was lactose containing (LC diet) $(150 \mathrm{~g} / \mathrm{d})$ and high protein $(112 \mathrm{~g} / \mathrm{d})$, the other normal protein and lactose free (LF diet) (protein $67 \mathrm{~g} / \mathrm{d}$ ), total energy content being similar. Patients were randomly divided into two equal groups and allocated (blind) to one of the diets. Tolerance and nitrogen balance were assessed over two three day periods on half and then full strength formulations. Severe intolerant symptoms were observed in $50 \%$ of patients on half strength and $94 \%$ of patients on full strength lactose containing diet with evidence of malabsorption of fluid, nitrogen, and fat. Despite high stool nitrogen losses $(3.75 \pm 1.04 \mathrm{~g} / \mathrm{d})$, however, positive nitrogen balance was achieved in most patients receiving the full strength LC formulation. On the other hand, the full strength LF diet was generally well tolerated and was associated with significantly lower faecal losses and positive nitrogen balance. The results indicate that high density lactose containing liquid formulae are poorly tolerated by severely malnourished black African patients, while lactose free formulae containing approximately $10 \mathrm{~g}$ nitrogen/d are well tolerated and result in positive nitrogen balance.

A recent survey has shown a high incidence of malnutrition among our hospitalised medical patients: over $80 \%$ of male and $50 \%$ of female patients had significant losses of protein and fat stores. ${ }^{1}$ As most of these patients have relatively normal gut absorption, nutritional support can be based on enteral regimens. There are at present only two such regimens locally available that are suitable for fine nasogastric infusion; one being milk based and therefore lactose containing, the other lactose free. A further study of ours has revealed the population to be predominantly lactose intolerant, ${ }^{2}$ with $90 \%$ of our medical ward patients showing a flat blood glucose response to oral lactose. Consequently, we might have anticipated problems with the milk based diet and designed the study to assess the practical importance of this.

Address for correspondence: Dr S J D O'Keefe, Gastrointestinal Unit, Groote Schuur Hospital, Observatory, Cape Town. 7925. Republic of South Africa. Received for publication 18 November 1983
PATIENTS

Forty malnourished male African patients requiring nutritional support were studied. They were randomly divided into two groups, one given lactose containing (LC) and the other given lactose free (LF) diets. Informed consent was obtained and patients were free to withdraw from study at any time. All patients were shown to have functional gastrointestinal tracts by normal xylose absorption tests - that is, increase in blood xylose greater than $1.67 \mathrm{mmol} / \mathrm{l}$ two hours after intake of $25 \mathrm{~g}$ xylose by mouth. Breakdown of disease patterns within each group is shown in Table 1. Respiratory infection predominated in keeping with our previous observation of a strong association between malnutrition and respiratory infection, in particular pulmonary tuberculosis. ${ }^{1}$

Anthropometric measurements showed both groups to be significantly malnourished as compared with matched healthy black African controls ${ }^{1}$ (Table 2). There were no significant differences in nutritional status between the two groups (TSF 
Table 1 Disease patterns

\begin{tabular}{lll}
\hline & $\begin{array}{l}\text { LC diet } \\
\text { group }\end{array}$ & $\begin{array}{l}\text { LF diet } \\
\text { group }\end{array}$ \\
\hline Respiratory infections & 10 & 13 \\
Pulmonary tuberculosis & 5 & 8 \\
Abdominal diseases (details see below) & 5 & 4 \\
Cardiovascular diseases & 2 & 1 \\
Renal diseases & 2 & - \\
Haematological diseases & 1 & 3 \\
\hline
\end{tabular}

Details of abdominal diseases: LC group: two cirrhotic patients, one amoebic liver abscess, one unexplained jaundice, one hepatomegaly. LF group: one cirrhosis, one hepatomegaly, one carcinoma stomach, one acute pancreatitis.

$4.9 \pm 1.9 \mathrm{~mm}$ in LC diet group; $4.2 \pm 2.8 \mathrm{~mm}$ in $\mathrm{LF}$ group).

\section{DESIGN OF STUDY}

Patients were studied while in a specific side ward section of the main medical ward. One of the investigators personally supervised the administration of the diets, patient symptoms, faecal, and urine collections. All patients were initially given half strength (manufacturer's recommendation, to allow for 'adaptation') diet for three days. For the second and third day, 24 hour urine and faecal collections were made in order to measure nitrogen balance. Tolerance to the diet was observed throughout the period together with a specific tolerance test as described below. From days four to six, full strength diet was given, and the above routine repeated on days five and six. Completeness of urine collections were checked by the consistency of the consecutive 24 hour creatinine contents.

DIETS

\section{Composition}

The two diets were given in the form recommended by the manufacturers and therefore not balanced to provide equal quantities of protein. Table 3 compares the composition. Vitamin and mineral content in both full strength formulations was
Table 3 Dietary composition (full strength daily intake)

\begin{tabular}{lcc}
\hline & $\begin{array}{c}\text { Medifeed } \\
(L C)\end{array}$ & $\begin{array}{l}\text { Ensure } \\
(L F)\end{array}$ \\
\hline Volume (ml) & 2000 & 2000 \\
Protein $(\mathrm{g})$ & 112 & 67 \\
Energy $(\mathrm{Kcal})$ & 2108 & 1911 \\
Carbohydrate $(\mathrm{g})$ & 280 & 262 \\
Lactose $(\mathrm{g})$ & 150 & 0 \\
Nitrogen $(\mathrm{g})$ & $17 \cdot 6$ & $10 \cdot 4$ \\
Fat $(\mathrm{g})$ & 60 & 67 \\
Osmolarity (mOsm/l) & 524 & 362 \\
\hline
\end{tabular}

sufficient to cover daily requirements [for details refer to Roussel Laboratories, Sandton, Johannesburg, 'Medifeed' (LC) and Ross/Abbott Laboratories, Aeroton, Johannesburg 'Ensure' (LF)]. Both diets were made up in the identical containers and were of similar appearance. Consequently patients were 'blind' as to which liquid they were receiving.

Diets were administered in the form of $400 \mathrm{ml}$ drinks every two hours between 800 am and 400 pm under direct supervision. Normal ward diet was withheld apart from water.

\section{Specific tolerance tests}

A protocol similar to that of a glucose or lactose tolerance test was followed, except the test diet consisted of $400 \mathrm{ml}$ of either half or full strength diet as described above. In the full strength formulation, this would contain $56 \mathrm{~g}$ total carbohydrate of which $30 \mathrm{~g}$ was lactose in the LC diet, and $52 \mathrm{~g}$ of non-lactose carbohydrate (mainly sucrose) in the LF diet. Blood samples were taken at 0 (fasting), 30, 60, 90, and 120 minutes after ingestion. Intolerant symptoms - for example, bloating, abdominal cramps, flatus, diarrhoea - were documented during the two hour test and continued over the following 24 hour period. The results were compared to the blood glucose response to $50 \mathrm{~g}$ glucose solution obtained in a previous study on similar patients. ${ }^{2}$

Table 2 Details of nutritional status of the two groups of patients studied (mean values $\pm S D$ )

\begin{tabular}{|c|c|c|c|c|c|c|c|}
\hline & $\begin{array}{l}\text { Age } \\
(y r)\end{array}$ & $\begin{array}{l}\text { Weight } \\
(k g)\end{array}$ & $\begin{array}{l}\text { Height } \\
(\mathrm{cm})\end{array}$ & $\begin{array}{l}\text { Triceps } \\
\text { skinfold } \\
(\mathrm{mm})\end{array}$ & $\begin{array}{l}\text { Arm circum- } \\
\text { ference } \\
(\mathrm{cm})\end{array}$ & $\begin{array}{l}\text { Plasma } \\
\text { albumin } \\
(\mathrm{g} / \mathrm{l})\end{array}$ & $\begin{array}{l}\text { Plasma } \\
\text { globulin } \\
(\mathrm{g} / \mathrm{l})\end{array}$ \\
\hline LC diet & $45 \cdot 9 \pm 13 \cdot 5$ & $55 \cdot 7 \pm 11 \cdot 5^{*}$ & $173 \cdot 7 \pm 5 \cdot 12$ & $4 \cdot 9 \pm 1 \cdot 9^{*}$ & $22 \cdot 7 \pm 3 \cdot 6^{*}$ & $36 \cdot 1 \pm 7 \cdot 4$ & $44 \cdot 5 \pm 11 \cdot 3$ \\
\hline LF diet & $39 \cdot 2 \pm 13 \cdot 4$ & $48 \cdot 1 \pm 9 \cdot 5^{*}$ & $163 \cdot 5 \pm 10 \cdot 2$ & $4 \cdot 2 \pm 2 \cdot 8^{*}$ & $21 \cdot 3 \pm 3 \cdot 4^{*}$ & $33 \cdot 7 \pm 7 \cdot 5$ & $38 \cdot 0 \pm 8 \cdot 7$ \\
\hline Controlst & $41 \pm 11$ & $73 \pm 13$ & $170 \pm 7$ & $9 \pm 4$ & $28 \pm 3$ & $35-50$ & $22-34$ \\
\hline
\end{tabular}

${ }^{*} \mathrm{p}<0.001$ unpaired Student's $t$ test.

+ See ref 1 . 
SAMPLE ANALYSIS

Urine and faeces

Nitrogen content was measured by micro-kjeldahl technique, fat content by standard saponification/alkali titration method. Blood glucose was measured after collection in oxalate containers, plasma separation, and analysis by glucose oxidase method.

\section{Results}

\section{DIETARY TOLERANCE}

(a) Symptoms (Table 4)

The lactose free diet was well tolerated at both half and full strength formulations by all but one patient who complained of nausea. On the other hand, the lactose containing diet was poorly tolerated. Fifty per cent of patients developed intolerant symptoms to the half strength formula while all but one developed similar complaints on the full strength formulation. Symptoms (in particular abdominal cramps and diarrhoea) were so severe in three patients that they could only complete 24 hours on the full strength formula.

\section{(b) Blood glucose responses}

Figures 1 and 2 summarise the changes in fasting blood glucose in response to an oral intake of $400 \mathrm{ml}$ half or full strength diet. The mean peak incremental rise on half strength lactose free diet was $1.56 \mathrm{mmol} / \mathrm{l}$, and $1.90 \mathrm{mmol} / \mathrm{l}$ on full strength. The latter result was similar to the rise after a similar quantity of glucose - that is, $2.2 \mathrm{mmol} / \mathrm{l}$ - in a similar group of patients reported previously. ${ }^{2}$ The peak response to the full strength lactose containing diet was significantly lower $(\mathrm{p}<0.05$, unpaired $t$ test $)$.

(c) Stool analysis

The accepted faecal nitrogen output is taken to be less than $1.5 \mathrm{~g} / 24 \mathrm{~h}^{3{ }^{34}}$ Consequently the mean

Table 4 Patient symptoms

\begin{tabular}{lcc}
\hline & LF diet & LC diet \\
\hline Half strength & & \\
$\quad$ No complaints & 19 & 6 \\
Diarrhoea and flatulence & 0 & 10 \\
Nausea and bloating & 1 & 1 \\
Loose stool & 0 & 1 \\
$\quad$ Constipation & 0 & 2 \\
Full strength & 19 & 1 \\
$\quad$ No complaints & 0 & 17 \\
Diarrhoea and flatulence & 1 & 2 \\
Nausea and bloating & 0 & 0 \\
Loose stool & 0 & 0 \\
$\quad$ Constipation & & \\
\hline
\end{tabular}

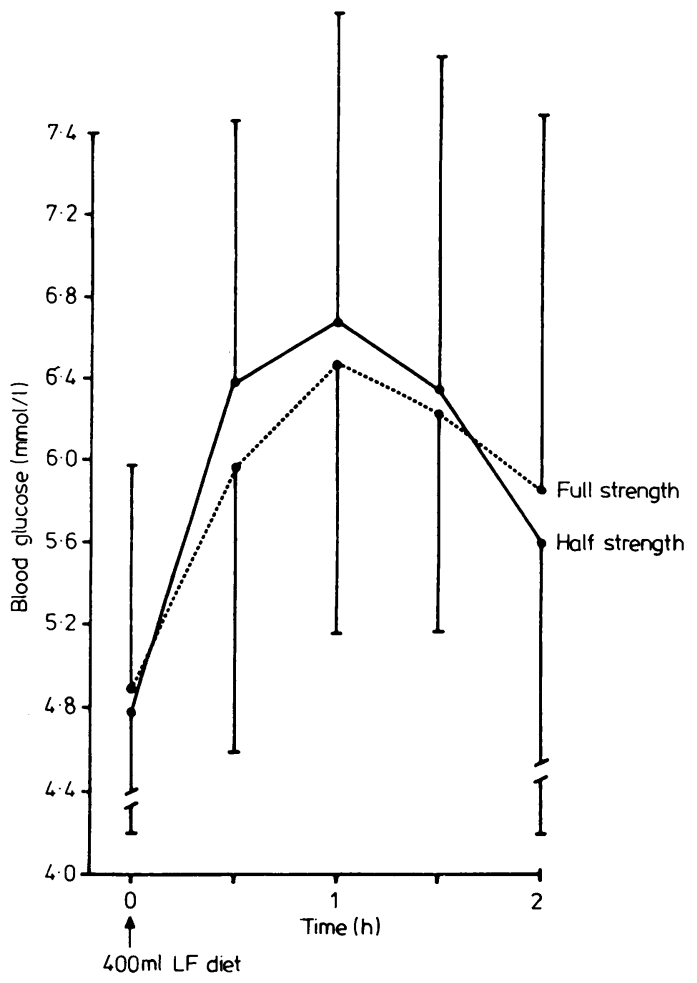

Fig. 1 Blood glucose response to bolus administration of $400 \mathrm{ml}$ of either half (-) or full strength (-..-) lactose free diets. 0 hrs $=$ fasting.

excretion was increased in all study groups, ranging from $1.93 \pm 1.12 \mathrm{~g} / 24 \mathrm{~h}$ on half strength lactose free diet to $3.75 \pm 2.03 \mathrm{~g} / 24 \mathrm{~h}$ on full strength lactose containing diet (Table 5). Expressed differentially, the quantity of dietary nitrogen not absorbed was 38 and $21 \%$ respectively, normal value being $8 \%{ }^{4}$

Stool nitrogen losses were significantly higher $(\mathrm{p}<0 \cdot 001$, Student's unpaired $t$ test $)$ in patients receiving the lactose containing diet. There was no direct relationship between dietary nitrogen intake and faecal loss - for example, a nitrogen intake of $9.0 \mathrm{~g}$ in half strength lactose containing diet was associated with a mean nitrogen loss of $2.96 \mathrm{~g} / \mathrm{d}$ while an intake of $10.1 \mathrm{~g}$ in full strength lactose free diet was associated with significantly less faecal nitrogen $2 \cdot 16 \mathrm{~g} / 24 \mathrm{~h}(\mathrm{p}<0 \cdot 01)$. On full strength lactose containing diet $80 \%$ - that is, 16 patients had losses in excess of $3.0 \mathrm{~g} / 24 \mathrm{~h}$, while only $25 \%$ (five patients) on the lactose free diet had such losses.

A summary of the full analysis of stool output on full strength diets is shown in Table 6. The major 


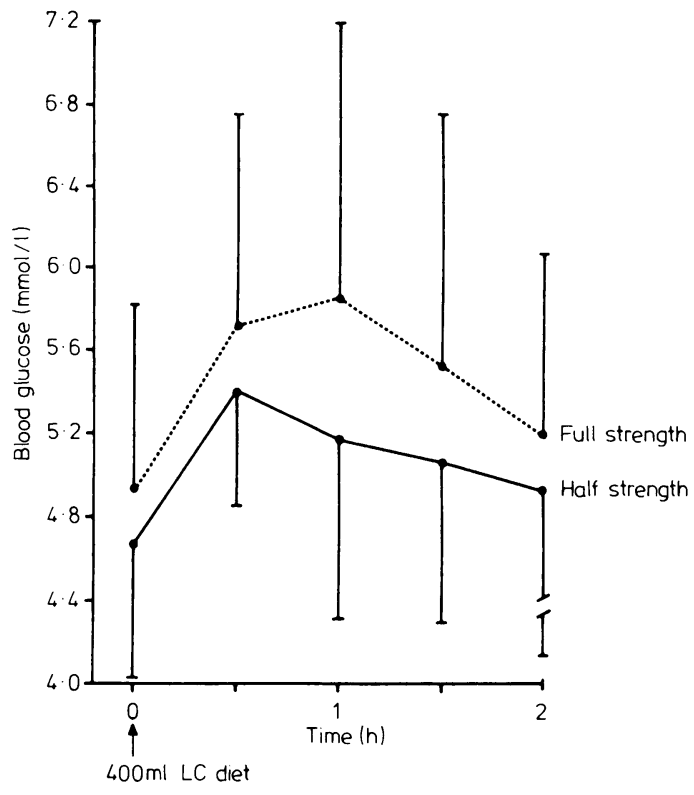

Fig. 2 As for Fig. 1, but response to $400 \mathrm{ml}$ of half and full strength lactose containing diets.

difference was in stool volume, those given the lactose containing diet excreting on average over a litre of fluid per day, in keeping with their symptoms shown in Table 4 . In addition to incomplete nitrogen and fluid absorption, fat malabsorption - that is, $>5 \mathrm{~g} / 24 \mathrm{~h}$ - was apparent in 18 patients on full strength LC diet and six patients on full strength LF diet.

\section{(d) Nitrogen balance}

Table 6 summarises the nitrogen balance results for half and full strength diets. It is evident that both half strength formulae were generally unable to maintain nitrogen equilibrium, unlike the full strength diets. Despite the high faecal nitrogen losses on the full strength lactose containing diet,
Table 624 hour stool analysis: on full strength formulae

\begin{tabular}{lcc}
\hline & $L C$ diet & $L F$ diet \\
\hline Weight & $1118 \cdot 5 \pm 711 \cdot 2 \mathrm{~g}^{*}$ & $280 \cdot 3 \pm 204 \cdot 7$ \\
pH & $5 \cdot 5 \pm 0 \cdot 5$ & $6 \cdot 0 \pm 0 \cdot 6$ \\
Nitrogen & $3 \cdot 75 \pm 2 \cdot 03 \mathrm{~g}^{*}$ & $2 \cdot 3 \pm 2 \cdot 1$ \\
Fat & $24 \pm 9.6 \mathrm{~g}^{*}$ & $6 \cdot 76 \pm 6 \cdot 81$ \\
\hline
\end{tabular}

Mean values $\pm \mathrm{SD}$, and where ${ }^{*}=\mathrm{p}<0 \cdot 05$ unpaired Student's $t$ test.

and relatively high urinary excretion, nitrogen intake was sufficiently high to cover such losses, resulting in an estimated mean positive daily balance of $4.9 \mathrm{~g}$ nitrogen.

\section{Discussion}

The most important finding of the present study was that the lactose containing diet was poorly tolerated. Despite the fact that nitrogen balance could be achieved on the full strength formulation, symptoms were severe enough to preclude its general prescription to severely malnourished hospital patients.

The reason for poor tolerance to the lactose containing diet was most likely to be because of the high lactose content as almost identical symptoms were detected in a previous study when a similarly malnourished group of black patients were given oral lactose tolerance tests: $90 \%$ developed intolerant symptoms. ${ }^{2}$ This was in keeping with previous observations of high incidence rates - that is, $>90 \%$ - of primary lactose intolerance in the Bantu races. ${ }^{56}$ It was noteworthy that Bowie et $\mathrm{l}^{7}$ were able to show a dramatic drop in stool weight when milk diet was changed to a carbohydrate free diet. The quantity of lactose given in the lactose containing liquid diet in bolus form was $15 \mathrm{~g}$ (half strength) and $30 \mathrm{~g}$ (full strength formulation). Extrapolating from the literature, one would expect about $50 \%$ of normal individuals with intestinal lactase deficiency to develop symptoms from ingestion of half strength, ${ }^{8}$ and $90 \%$ to develop

Table 5 Nitrogen balance data for both groups of patients on half and full strength formulations (mean values $\pm S D$ ) (based on 48 hour collections)

\begin{tabular}{|c|c|c|c|c|}
\hline & \multicolumn{2}{|l|}{$L C$ diet } & \multicolumn{2}{|l|}{$L F$ diet } \\
\hline & Half strength & Full strength & Half strength & Full strength \\
\hline Nitrogen in diet $(g / d)$ & $9 \cdot 0$ & $18 \cdot 0$ & $5 \cdot 04$ & $10 \cdot 08$ \\
\hline Nitrogen in urine $(\mathrm{g} / \mathrm{d})$ & $6 \cdot 1 \pm 1 \cdot 8$ & $9 \cdot 35 \pm 3 \cdot 93$ & $5 \cdot 3 \pm 2 \cdot 2$ & $5 \cdot 4 \pm 2 \cdot 3$ \\
\hline Nitrogen in stool $(\mathrm{g} / \mathrm{d})$ & $2 \cdot 96 \pm 2 \cdot 44$ & $3 \cdot 75 \pm 2 \cdot 03$ & $1.93 \pm 1 \cdot 12$ & $2 \cdot 16 \pm 1 \cdot 69$ \\
\hline Nitrogen balance $(\mathrm{g} / \mathrm{d})$ & $-0 \cdot 06$ & $+4 \cdot 9$ & $-2 \cdot 19$ & $+2 \cdot 52$ \\
\hline
\end{tabular}


symptoms to the full strength lactose containing diet. ${ }^{9}$ These figures correspond very closely to our actual observations. Another explanation could be the higher osmolarity of the lactose containing diet. This is an unlikely contender, however, as the half strength lactose containing solution (osmolarity 262 $\mathrm{mOsm} / \mathrm{l}$ ) was associated with more intolerance than the higher osmolarity $(362 \mathrm{mOsm} / \mathrm{l})$ full strength lactose free solution.

It is of interest that Silk and coworkers noticed no significant intolerance to a similar lactose containing solution when it was given as a constant nasogastric infusion. ${ }^{10}$ As tolerance is related to the load of lactose given, ${ }^{11}$ it remains possible that slow continuous infusion will be better tolerated. This has been attempted on our wards with poor results. Zulu patients strongly resist the insertion of nasogastric tubes as they believe it indicates the end is near. The origin of this misconception presumably arises from their observation of the tube feeding of terminal unconscious patients. On the other hand, they are very happy to take regular liquid drinks in the manner followed in our present study.

Subclinical intestinal malabsorption is well recognised in the tropics. ${ }^{12}{ }^{13}$ Our observation of mildly impaired nitrogen and fat absorption in some patients is consistent with this hypothesis. The explanation is probably complex as it has been related to malnutrition $\mathrm{per} s e^{121415}$ abnormal absorptive mucosa $a^{16-18}$ and subclinical tropical sprue, ${ }^{19}$ and also bacterial and parasitic overgrowth. ${ }^{20-23}$ Although detailed work up of intestinal absorption was not done (apart from xylose absorption tests) in the present study, we have previously reported a high incidence of small intestinal mucosal abnormalities in a similarly malnourished group of black Africans. ${ }^{24}$ In the present study we noted a high incidence of fluid, nitrogen, and fat malabsorption in the group of patients given the lactose formula. Debongie et $a^{25}$ showed reduced protein, fat, calcium, magnesium, and phosphorus absorption by the ileum in lactose intolerant normal volunteers. Consequently it seems reasonable to ascribe the malabsorption seen in our lactose dietary group to the added insult of lactose maldigestion on an already compromised gastrointestinal tract. This is in keeping with previous reports of fat malabsorption in lactose intolerant patients after gastric surgery. ${ }^{27} 28$

Our main conclusion is that lactose free liquid formula diets containing approximately $10 \mathrm{~g}$ nitrogen and $2000 \mathrm{Kcal}$ will provide adequate nutritional support for most of our malnourished adult African patients. On the other hand, high protein lactose containing regimens should be avoided, even at half strength dilution, not so much for reasons of malabsorption, but more for patient comfort. It must be stressed that we cannot extrapolate our results to the normal population. Indeed milk products are part of the normal diet and remain very popular despite the high incidence of primary lactose intolerance.

We thank Natal University Grants Committee for financial assistance and Sr D M Steven for typing the manuscript.

\section{References}

1 O'Keefe SJD, Thusi D, Epstein S. The fat and the thin: a survey of nutritional status and disease patterns in urbanised black South Africans. S Afr Med J 1983; 63: 679-83.

2 O'Keefe SJD, Adam JK. Primary lactose intolerance in Zulu adults. $S$ Afr Med J 1983; 63: 778-80.

3 Garza C, Scrimshaw NS, Young VR. Human protein requirements: inter-relationships between energy intake and nitrogen balance in young men consuming the $1973 \mathrm{FAO} / \mathrm{WHO}$ safe level of eggs protein with added non-essential aminoacids. $J$ Nutr 1978; 108: $90-6$.

4 Davidson S, Passmore R, Brock JF. Human nutrition and dietetics. Edinburgh: Churchill Livingstone, 1972: 50.

5 Cooke GC, Kajubi SK. Tribal incidence of lactase deficiency in Uganda. Lancet 1966; 1: 725-30.

6 Jersky J, Kinsley RH. Lactase deficiency in the South African Bantu. S Afr Med J 1967; 41 : 1194.

7 Bowie MD, Brinkman EL, Hansen JDL. Diarrhoea in protein calorie malnutrition. Lancet 1963; 2: 550.

8 Solomons NW, Garcia-Ibanez R, Viteri FE. Hydrogen $\left(\mathrm{H}_{2}\right)$ breath test of lactose absorption in adults: the applications of physiological doses and whole cow's milk sources. Am J Clin Nutr 1980; 33: 545-54.

9 Jones DV, Latham MC, Kosikowski FV, Woodward G. Symptom response to lactose-reduced milk in lactose-intolerant adults. Am J Clin Nutr 1976; 29: 633-8.

10 Keohane PP, Attrill H, Jones BJM, Brown I, Frost P, Silk PBA. Influence of lactose intolerance and Clostridium difficile in the pathogenesis of enteral feeding associated diarrhoea. Clin Nutr 1983; 1: 259-64.

11 Bayless TM, Rothfield B, Massa C, Wise L, Paige DM, Bedine MS. Lactose and milk intolerance: clinical implications. N Engl J Med 1975; 292: 1156-9.

12 Falaiye JM. Present status of subclinical intestinal malabsorption in the tropics. Br Med J 1971; 4: 454-8.

13 Moshal MG, Hift W, Kallichurum S, Pillay K. Malabsorption and its causes in Natal. S Afr Med J 1973; 47: 1093-103.

14 Leblond CP, Walker BE. Renewal of cell populations. 
Physiol Rev 1956; 36: 255-76.

15 Leblond CP, Messner B. Renewal of chief cells and goblet cells in the small intestine as shown by radioautography after injection of thymide- $\mathrm{H} 3$ into mice. Anat Rec 1958; 132: 247-59.

16 Burman D. The jejunal mucosa of kwashiorkor. Arch Dis Child 1965; 40: 526.

17 Stanfield JP, Hutt MSR, Tunnecliffe R. Intestinal biopsy in kwashiorkor. Lancet 1965; 2 : 519.

18 Martins Campos JV, Fagundes Neto U, Patricio FRS, Webha J, Carvalho AA, Shiner M. Jejunal mucosa in marasmic children. Clinical, pathological and fine structural evaluation of the effect of protein-energy malnutrition and environmental contamination. $A m J$ Clin Nutr 1979; 32: 1575-91.

19 Klipstein FA, Samloff IM, Schenk EA. Ann Intern Med 1966; 64: 575.

20 Lindebaum J. Malabsorption during and after recovery from acute intestinal infection. $\mathrm{Br}$ Med J 1965; 2: 326-9.

21 Milner PF, Irvine RA, Barton CJ, Bras G, Richards R. Intestinal malabsorption in strongyloides stercoralis infestation. Gut 1965; 6: 574-81.

22 Amini F. Giardiasis and steatorrhoea. J Trop Med Hyg
1963; 66: 190-2.

23 Tandon BN, Das BC, Saraya AK, Deo MG. Functional and structural studies of small bowel in ankylostomiasis. $\mathrm{Br} \mathrm{Med} J$ 1966; 1: 714-6.

24 O'Keefe SJD, Spitaels JM, Roost R, Gregory M, Naicker $M$. The relationship between severe malnutrition and jejunal mucosal abnormality in the Black South African adult. Proc SA Gastroenterology Society Meeting, Sun City, Bophuthatswana, 24-27 October 1982.

25 Debongnie JC, Newcomer AD, McGill DB, Phillips SF. Absorption of nutrients in lactase deficiency. Dig Dis Sci 1979; 24: 225-31.

26 Phillips SP. Lactose malabsorption and gastrointestinal function: effects on gastrointestinal tract and absorption of other nutrients. In: Paige DM, Bayless TM, eds. Lactose digestion: clinical and nutritional implications. Baltimore and London: The Johns Hopkin University Press, 1981: 55.

27 Banks S, Barbezat GO, Marks IN. Post-gastrectomy steatorrhoea due to intestinal lactose deficiency. $S A f r$ Med J 1966; 40: 597-9.

28 Paige DM, Graham GC. Nutritional implications of lactose malabsorption. Pediatr Res 1972; 6: 329. 